\title{
Framtak Balbos og próun samskipta milli Ítalíu og Íslands
}

by Ragnar Borg

Hvaða áhrif hafði koma flugsveitar Balbos á viðskipti við Ítalíu?

Pegar Balbo kom hingað til lands var lífið á Íslandi saltfiskur. Petta var nánast eina útflutningsvaran til Ítalíu og hafði verið seldur allt frá árinu 1895. Fram að árinu 1919 var útflutningurinn skrikkjóttur og ekki mikil en bað ár tók salan stökk og jókst sala á saltfiski ár frá ári. Árið 1925 fékk Richard Thors, forstjóri hjá Kveldúlfi sem átti marga togara, Hálfdán Bjarnason til að setjast að í Genúa og stjórna sölunni á Ítalíu. Ég kynntist Hálfdáni og heilsaði upp á hann tvisvar, en pá var hann orðinn mjög fullorðinn. Halldór var á sínum tíma ræðismaður Íslands á Ítalíu og hjálpaði íslenskum kaupmönnum við að ná samböndum við ítalska framleiðendur. Árið 1933 og 1935 voru metár. Viðskipti voru opin pannig að ítalskir saitfiskkaupmenn greiddu fiskinn í peningum sem voru yfirfærðir í íslenska banka. Árið 1935 verður bó breyting á. Ítalir kröfðust pess nú að Íslendingar keyptu ítalskar vörur í staðinn fyrir saltfiskinn. Á Íslandi voru ströng innflutningshöft og purfti leyfi til að kaupa hvað sem var frá útlöndum. Var samið við Ítali um að Danir myndu kaupa ítalskar vörur fyrir íslenska saltfiskinn og greiða íslendingum í dönskum krónum.

Fyrirtæki mitt, G.Helgason \& Melsteð h.f. var stofnað árið 1930. Páll B. Melsteð, annar eigendanna, pekkti vel til vefnaðarvöru og fór hann nokkrar ferðir til Ítafíu. Fyrstu ferðina fór hann árið 1933 og náði sér í viðskiptasambönd, aðallega í vefnaðarvöru. Hann varð pó að lúta afar ströngum skilyrðum um innflutning hingað, en hann var afar útsjónasamur og seldi til Ítalíu æðardún, selskinn, refaskinn héðan frá Íslandi og saltfisk, sem hann keyti í Færeyjum. Hafði hann pannig nokkurn kvóta til að kaupa vörur á Ítalíu og flytja hingað. Prír stórir aðilar voru innflytjendur á vefnaðarvöru pessi ár. Melsteð, Samband Íslenskra Samvinnufélaga og Edda. Eitt sinn var Páli B. Melsteð einum of frakkur, að mati innflutningsráðs, keypti meira en hann mátti. Átti að flytja sendinguna aftur til Ítalíu, en fallist var á að pessir prír aðilar skiptu sendingunni milli sín. G.Helgason \& Melsteð h.f. flutti inn alls konar efni til að sauma kjóla, peysuföt, smávörur alls konar, tilbúinn fatnað og metravörur. Auk pess var gerður samningur við Olivetti sem var stærsti framleiðandi á skrifstofuvélum á Ítalíu.

Enginn vafi er á pví að menn féllu í stafi er 24 ítalskar flugvélar lentu hér í Reykjavík árið 1933. •аð opnaðist fyrir mönnum að pað voru ekki einungis vefnaðarvörur sem framieiddar voru á Ítalíu heldur alls konar hátæknivörur. Miðað við innflutning á ítöiskum vörum árið 1933 fjórfaldaðist salan árið 1936 og var svo næstu árin, fram að stríðinu en pá tók fyrir alla verslun við Italíu. Á priðja áratugnum höfðu komið nokkrir stórir Fiat rútubílar og nokkrir fólksbílar en varla neitt annað. Höftin hér á landi leyfðu ekki að menn könnuðu pennan markað. Strax eftir stríðið var farið að flytja saltfisk til Italíu á ný, en sama sagan var hér heima, höft og aftur höft. G. 
Helgason \& Melsteð h.f. fór að flytja inn Olivetti skrifstofuvélar af krafti árið 1957. Var ég sendur til náms til að læra á hinar ýmsu vélar og lærði ég sérstaklega kerfisfræðina til að stilla bókhaldsvélar til hinna ýmsu verka. En til dæmis um höftin get ég sagt að við urðum að fá leyfi Fjárhagsráðs til að flytja inn hverja eina reiknivél. Með Olivetti vélunum sannaðist að ítölsk smíði gaf ekkert eftir í gæðum. Svo var farið að flytja inn ítölsk húsgögn og alls konar vélar og eykst innflutningur frá Ítalíu með hverju ári.

Nú eru öll viðskipti opin og á Ítalíu fæst allt. Tæknivæðing er bar í hámarki og hönnun heimsfræg. Ég er á pví að Balbo og menn hans sem komu hingað árið 1933 hafi með framkomu sinni og djörfung vakið mikla athygli á Ítalíu og opnað augu íslenskra innflytjenda á ítölskum vörum en peir urðu að bíða í um 20 ár til að koma hjólunum til að snúast að gagni.

Ímyndið ykkur hvernig pað var fyrir Balbo og menn hans að fljúga megnið af leiðinni frá Írlandi til Reykjavíkur í poku og flughæðin var 30 metrar, veðurlag á Atlantshafinu nánast ópekkt en flugvélarnar peirra reyndust fluginu vaxnar og aliar heilu höldnu í Reykjavík.

RAGNAR BORG is former honorary consul of Italy in Iceland, secretary of the Dante Alighieri Society-active in promoting Italian culture in Iceland-since its establishment in 1994, and a renowned numismatic expert. As a businessman, he has been importing Italian products to Iceland since the 1950 . 